\title{
SHEKH MA SHIERAKI ANNI: TYPOLOGY OF A FICTIONAL Language Created for Artistic Purposes
}

\author{
Matt Destruel
}

\section{INTRODUCTION}

George R. R. Martin is an American author best known for his fantasy novel series titled A Song of Ice and Fire. The epic saga follows numerous characters across interlocking storylines, in a medievalesque world filled with supernatural elements. This paper mostly concerns the tale of the daughter of a king who was murdered during a civil war. Exiled to a different continent for her own protection, the young princess embarks on a journey to return to her homeland and claim the throne that was stolen from her family. In the process, she meets the nomadic tribe of horse-riding warriors known as the Dothraki, and becomes married to their leader. She must learn and adopt their customs and traditions, and more importantly, their language.

In 2008, satellite television network HBO started working on a televised adaptation of the book series, which created the need for a full-fledged Dothraki language. Indeed, if Martin invented the language for his novels, he only created a limited number of lexical terms and idioms. American linguist and language creator David J. Peterson was thus hired to fully create all aspects of the language, including morphology, syntax, and phonology. Peterson has given many interviews regarding his language creation process, as well as the decisions he faced during the development of Dothraki. Upon deciding to study the typology of Dothraki, I assumed, despite the artificial nature of the language, that it would conform to linguistic universals such as Greenberg's (1963) list. This assumption is supported by the following extract from an interview with Peterson:

I don't believe it was Mr. Martin's intention for the humans in his books-vicious Dothraki horse warriors included - to be radically different from humans in our world (at least with respect to their higher cognitive functions). As such, I made it my goal to create [a language] that would look and feel just like any natural language (English, Turkish, Hawaiian, ASL, etc.), exemplifying the kind of variability that one would find in natural human languages. As linguistic universals tend to describe the way natural languages behave in the real world, it shouldn't be surprising to find that Dothraki doesn't break many. ("Dothraki response to a call for science in a created language". 2010.)

The goal of this paper is to establish a descriptive survey of Dothraki, using typological data as the main source of information, and then applying linguistic tools to determine if the language is typologically tractable. In order to do so, I selected Greenberg's (1963) work on linguistic universals, based on its relevance and prevalence even to this day, despite the many other contributions that have been made in the field of typology. Each universal will therefore be applied to the Dothraki language, in order to see if it indeed conforms to most - if not all - of them.

\section{Dothraki Vocabulary Used in this Paper}

- Khal [xal] noun - title used for the leader of a Dothraki horde, king

- Khaleesi [xaleesi] noun - queen, wife of a khal

- Khalasar [xalasar] noun - a horde loyal to a single khal 
- Arakh [arax] noun - traditional Dothraki weapon, mix of sword and scythe in shape and size

- Andals [ændəl]/ noun - dominant ethnic group in Westeros, continent located across the sea from the Dothraki-native-continent of Essos

Table of Abbreviations

\begin{tabular}{|l|l|}
\hline Abbreviation & Meaning \\
\hline $1,2,3$ & first, second, third person \\
\hline ABL & ablative \\
\hline ACC & accusative \\
\hline ALL & allative \\
\hline ANIM & animate \\
\hline CAUS & causative \\
\hline DEMADJ & demonstrative adjective \\
\hline DUR & durative \\
\hline FORM & formal \\
\hline FUT & future tense \\
\hline GEN & genitive \\
\hline IMP & imperative \\
\hline IMPRF & imperfective \\
\hline INAN & inanimate \\
\hline INF & infinitive \\
\hline INFORM & informal \\
\hline NEG & negative \\
\hline NOM & nominative \\
\hline OBJ & object \\
\hline P & plural \\
\hline PREP & preposition \\
\hline PRES & present tense \\
\hline PST & past tense \\
\hline Q & question word \\
\hline RELPRO & relative pronoun \\
\hline RFL & reflexive \\
\hline S & singular \\
\hline VOC & vocative \\
\hline & \\
\hline
\end{tabular}

\section{DesCriptiVe SURVEY OF DOTHRAKI}

\section{About Sentences}

- The Dothraki are a race of nomadic horse riders. As a result, a lot of their culture, and language, revolves around their horses. The name Dothraki itself comes from the verb dothralat 'to ride', while the word for foreigner, ifak, literally means 'walker'. Many idioms make reference to horses, such as the following greeting:

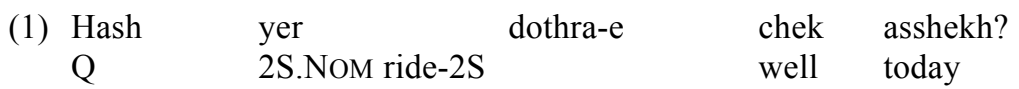

'How are you today?' (lit. 'Do you ride well today?)

- The basic word order in Dothraki is Subject-Verb-Object: 


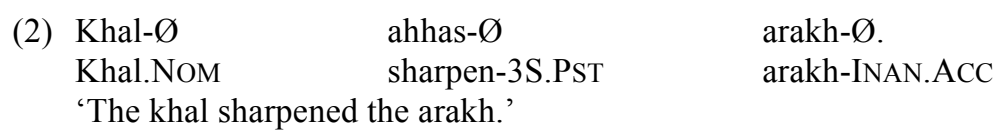

\section{About Verbs}

- The infinitive form of a verb ends in -(l)at. Stripping a verb of this ending gives the stem that is used to conjugate it. The infinitive ending is realized as -at if the stem ends in a consonant, and as -lat if it ends in a vowel.

- Dothraki doesn't distinguish between progressive and perfective. Sentence 7 below can either mean 'I mount the steed', or 'I am mounting the steed'.

$\begin{array}{lll}\text { (3) Anha } & \text { saj-ak } & \text { sajo-es. } \\ \text { 1S.NOM } & \text { mount-1S } & \text { steed-ACC }\end{array}$

- There is no copula in Dothraki. ' $\mathrm{X}$ is $\mathrm{Y}$ ' is expressed as ' $\mathrm{X}$.Nom Y.Nom' (past: $\mathrm{X} . \mathrm{NOM}$ Y.ABL, Fut: X.Nom Y.ALL) or by turning an adjective into a verb: 'X.Nom V=to be Y'.

(4) Ashefa- $\varnothing$ lain-a.

River-S.Nom be beautiful-3S

'The river is beautiful'

- Causative are created by reduplicating the first letter of the verb, adding an ' $a$ ' in front if it is not a vowel. For example, the following pairs represent basic verbs and their causative equivalents: drivolat/addrivat "to die/to kill (cause to die)"; nithat/annithat "to feel pain/to cause pain", raggat/arraggat "to choke on something/to choke someone (cause to choke)".

- Dothraki has five cases: nominative, accusative, genitive, ablative and allative. The subject of the sentence is usually in the nominative case (often represented with a $\varnothing$ marker), while the object is in the accusative. Examples will be studied in the third part of this paper.

\section{About Noun Phrases}

- Dothraki does not have definite or indefinite articles. Common nouns appear on their own, and context alone can help differentiate between 'an arakh' and 'the arakh' in (2) for example.

- Dothraki is prepositional, and prepositions assign case to the noun they precede (torga 'under' marks genitive).

(5) Rhoa torga osoleth-i.

Beast.NOM under bridge-GEN

'The beast is under the bridge.'

- Adjectives and possessive pronouns are placed after the noun they modify.

(6) Lajak-is ivezh-i mori.

Warrior-P.ACC wild-P 3P.GEN

'Their wild warriors.' 
- Dothraki distinguishes alienable possession from inalienable. Alienable possession is indicated with the genitive, whereas inalienable possession is indicated with the ablative. Inalienable possession is used primarily with body parts.

(7) Jan

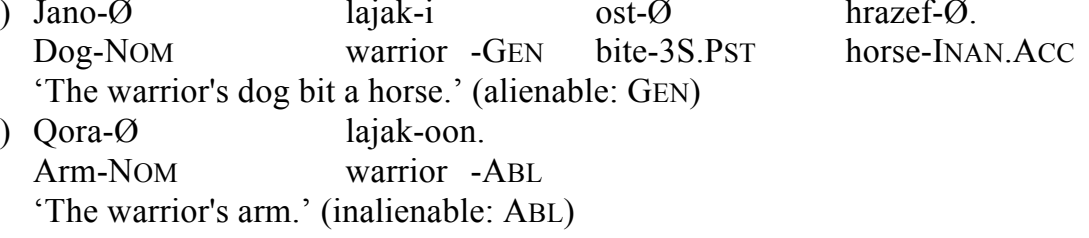

- Dothraki nouns come in two grammatically different types: animate or inanimate. However, nouns are not necessarily deemed animate because they represent something active and/or alive (hake 'name' is animate), and similarly, an inanimate noun might not refer to something passive and/or lifeless (alegra 'duck' is inanimate). Animacy seems to be somewhat random, much like gender can be in the Romance Languages. However, a few general rules can be established:

- humans are always animate (e.g.: father, son)

- mass-nouns are inanimate (e.g.: milk, response)

- large homogenous groups are inanimate (e.g.: horde, caravan)

- animals are usually inanimate (e.g.: horses, dogs) but marked members of a species are animate (e.g.: steed, stallion)

Occasionally, a word can be either animate or inanimate. For example, the word lekh can be animate, in which case it means 'language', or inanimate, in which case it means 'tongue'.

- Plurality can be observed on nouns and adjectives (case markers) and on verbs (tense endings). Generally, Dothraki requires subject-verb agreement and noun-adjective agreement, and different case markers and verb endings are used to mark the singular and the plural. However, these markers are sometimes the same for singular and plural, erasing any plurality distinctions. As a result, plurality is often inferred from context in Dothraki:

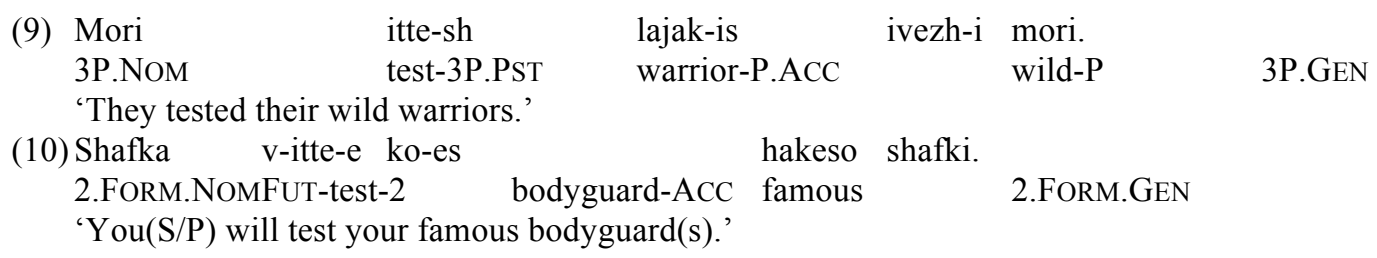

In (5), plurality is explicit on every word: the pronoun mori is marked for plurality, there is agreement between the subject and the verb as seen in the ending $-s h$, and the accusative marker on lajak would be different if the noun was singular. On the other hand, sentence (6) is completely ambiguous. Indeed, the use of the formal second person pronoun shafka makes it impossible to determine if the subject is singular or plural. Moreover, the tense ending $-e$ is the same for singular and plural subjects second person subjects. Finally, the accusative marker -es is used for both singular and plural animate nouns. Therefore, any indication of singularity or plurality is neutralized.

Plurality also ties to the concept of animacy. Indeed, animate nouns have different cases for singular and plural, whereas there is no such difference for inanimate nouns. Adjectives do 
agree with the noun they modify however, and a singular or plural marker might be evident on the adjective, even if the noun itself is ambiguous.
(11) Adra-si
verven-i vekh-i
Turtle-ANIM.GEN
violent-P
exist/be present-3P
here

In (11), Plurality is not marked in adrasi: indeed, the verb vekhat always assigns the genitive case to its subject, and the genitive singular and plural markers are the same: $-s i$. However, since adra 'turtle' is an animate noun, the adjective and the verb must still agree with it in number.

- Dothraki does not have gender:

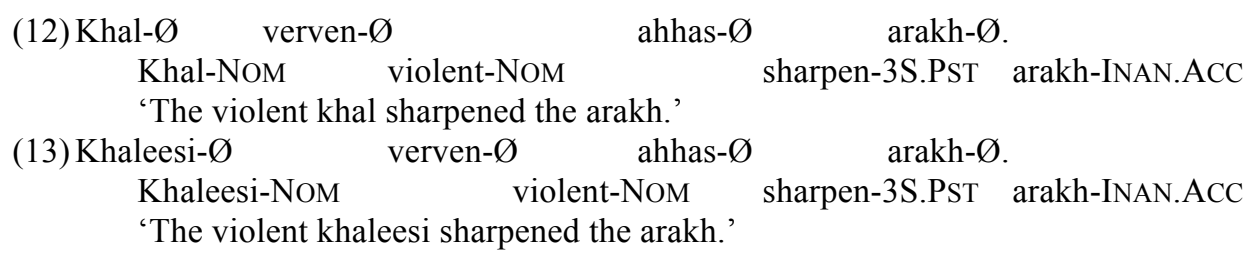

There is no trace of gender differences between these two otherwise identical sentences. Adjectives do not agree in gender with the noun they modify, and nouns are not inflected for gender. Additionally, the absence of definite and indefinite articles in Dothraki prevents their use as gender indicators.

- Comparative adjectives are derived from adjectives via the circumfix $a$-Adj-(a)n (realized $a$-Adj-an if the adjective ends in a consonant, or $a$-Adj- $n$ if the adjective ends in a vowel). These adjectives can then be turned into verbs by adding the infinitival suffix -(l)at:

haj: strong

ahajan: stronger

ahajanat: to be stronger hakeso: famous

ahakeson: more famous

ahakesonat: to be more famous

\section{APPLICABILITY OF GREenBeRg's LINGUISTIC UNIVERSALS}

Note: Some of Greenberg's (1963) universals do not apply to Dothraki or are somehow irrelevant in the language. This section will focus on pertinent universals, but the full list and its analysis can be found in the appendix.

1. In declarative sentences with nominal subject and object, the dominant order is almost always one in which the subject precedes the object.

In Dothraki, Greenberg's (1963) Universal \#1 is confirmed. We can see in sentence (i) below that the subject of the sentence, khal, appears before the verb ahhas, which is itself followed by a direct object. Therefore, the word order in Dothraki is SVO.

(i)

(ii) 
'I mount the steed.'

Therefore, Dothraki is fully consistent with Universal \#1.

2. In languages with prepositions, the genitive almost always follows the governing noun, while in languages with postpositions it almost always precedes.

In Dothraki, Greenberg's (1963) Universal \#2 is confirmed. Sentence (iii) below shows that Dothraki uses prepositions, since torga 'under' appears before the noun osolethi 'bridge'. Additionally, the sentence (iv) displays a genitive construction:

(iii)

Rhoa
Beast.Nom
'The beast is under the bridge.'

(iv)

lajak-i

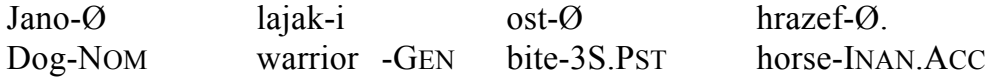

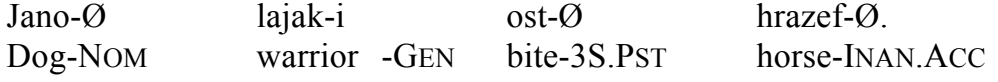

osoleth-i.

bridge-GEN

'The warrior's dog bit a horse.'

Here, we can see that the genitive lajaki follows the governing noun jano. Therefore, based on sentences (iii) and (iv), Dothraki is fully consistent with Universal \#2.

9. With well more than chance frequency, when question particles or affixes are specified in position by reference to the sentence as a whole, if initial, such elements are found in prepositional languages, and, if final, in postpositional.

In Dothraki, Greenberg's (1963) Universal \#9 is confirmed. We established in Universal \#8 that question particles are always sentence initial, while Universal \#2 indicates that Dothraki is a prepositional language. Therefore, Dothraki is fully consistent with Universal \#9.

14. In conditional statements, the conditional clause precedes the conclusion as the normal order in all languages.

In Dothraki, Greenberg's (1963) Universal \#14 is confirmed. The conditional precedes the conclusion either syntactically or semantically:

(v)

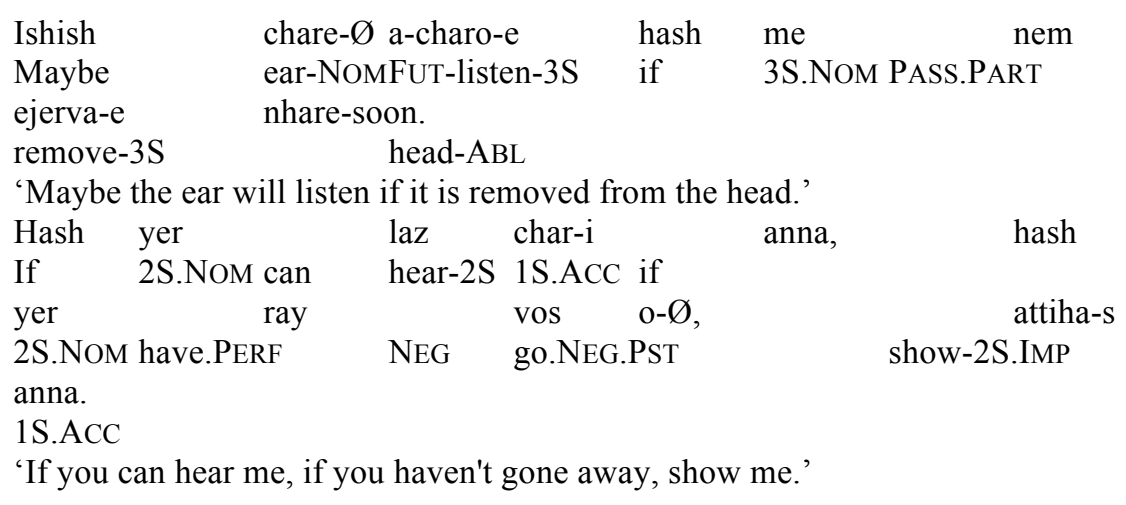

In sentence (xi), the meaning of the sentence indicates that the condition - the ear being removed from the head - precedes the conclusion - the ear listening. In (xii), we can see that the conditions precedes the conclusion through the syntax itself: the conditions are the first and 
second clauses in the sentence (If you can hear me, if you haven't gone away), while the conclusion comes last (show me). Therefore, Dothraki is consistent with Universal \#14.

15. In expressions of volition and purpose, a subordinate verbal form always follows the main verb as the normal order except in those languages in which the nominal object always precedes the verb.

In Dothraki, Greenberg's (1963) Universal \#15 is confirmed. The subordinate verbal form follows the main verb:

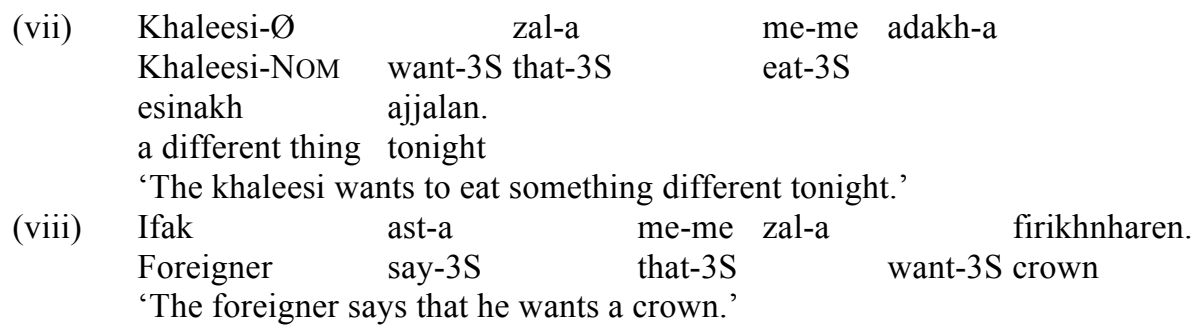

In both sentences, we can see that the subordinate verb (for example adakha 'eats' in (xiii)) follows the main verb (for example zala 'wants'). Therefore, Dothraki is consistent with Universal \#15.

20. When any or all of the items (demonstrative, numeral, and descriptive adjective) precede the noun, they are always found in that order. If they follow, the order is either the same or its exact opposite.

In Dothraki, Greenberg's (1963) Universals \#20 is partially confirmed. We have seen in Universal \#18 and 19 that descriptive adjectives always follow nouns, whereas demonstrative and numeral adjectives precede nouns. Sentence (xviii) below is a case where a demonstrative and a numeral are used together:

We can see that the demonstrative adjective jin precedes the numeral fekh 'seven' when they are used together. Therefore, Dothraki is partially consistent with Universal \#20.

22. If in comparisons of superiority the only order, or one of the alternative orders, is standardmarker-adjective, then the language is postpositional. With overwhelmingly more than chance frequency if the only order is adjective-marker-standard, the language is prepositional.

In Dothraki, Greenberg's (1963) Universals \#22 is confirmed. We saw in Universal \#2 that Dothraki is prepositional. The sentences below are examples of comparisons of superiority:
(x)
Jorah- $\varnothing$ Andahl-i ahajan-a
Jorah-Nom Andahl.GEN
be stronger-3S
khaleesi-soon
'Jorah the Andal is stronger than the khaleesi.'
(xi)
Risz- $\varnothing$ ahakeson-a
Son-Nom be more famous-3S
'The son is more famous than the child.'
yalloon
child-ABL
khaleesi-ABL 
We can see that the adjectives haj 'strong' and hakeso 'famous', turned into verbs in Dothraki, appear before the standard of comparison: khaleesisoon 'khaleesi-ABL' in (xxi) and yalloon 'child-ABL' in (xxii). Therefore, Dothraki is consistent with Universal \#22.

23. If in apposition the proper noun usually precedes the common noun, then the language is one in which the governing noun precedes its dependent genitive. With much better than chance frequency, if the common noun usually precedes the proper noun, the dependent genitive precedes its governing noun.

In Dothraki, Greenberg's (1963) Universals \#23 is confirmed. We established in Universal \#2 that the governing noun precedes the genitive, and sentence (xxiii) below shows that proper nouns precede common nouns.

$$
\begin{aligned}
& \text { Daenerys Targaryen- } \varnothing, \quad \text { Mayes } \\
& \text { Daenerys Targaryen-NOM mother.ACC } \\
& \text { 'Daenerys Targaryen, Mother of Dragons.' }
\end{aligned}
$$

Zhavvor-si

dragon-P.AMIM.GEN

We can see that the proper noun 'Daenerys Targaryen' precedes the common noun Mayes Zhavvorsi 'Mother of Dragons'. Therefore, Dothraki is consistent with Universal \#23.

25. If the pronominal object follows the verb, so does the nominal object.

In Dothraki, Greenberg's (1963) Universals \#25 is confirmed. Both pronominal and nominal objects follow the verb:

\begin{tabular}{llr} 
(xiii) & Mori a-tih-i & \multicolumn{1}{c}{ mae. } \\
& 3P-Nom FUT-see-3S & 3S.ACC \\
'They will see it.' & \multicolumn{1}{c}{ sajo-es. } \\
(xiv) & Anha saj-ak & steed-ACC \\
& 1S.Nom mount-1S &
\end{tabular}

We can see that the nominal object sajoes 'steed' and the pronominal object mae 'he/she/it' both follow their respective verbs. Therefore, Dothraki is consistent with Universal \#25.

26. If a language has discontinuous affixes, it always has either prefixing or suffixing or both.

In Dothraki, Greenberg's (1963) Universals \#26 is confirmed. Dothraki uses discontinuous affixes, and is prefixing and suffixing:

\begin{tabular}{|c|c|c|c|c|}
\hline (xv) & $\begin{array}{l}\text { tihi-lat } \\
\text { look at-INF } \\
\text { 'to look at' }\end{array}$ & $\rightarrow$ & (xvi) & $\begin{array}{l}\text { vi-tihi-r-at } \\
\text { DuR-look at-DUR-INF } \\
\text { 'to observe' }\end{array}$ \\
\hline (xvii) & $\begin{array}{l}\text { e-lat } \\
\text { go-INF } \\
\text { 'to go' }\end{array}$ & $\rightarrow$ & $\begin{array}{l}\text { (xviii) } \\
\text { (xix) }\end{array}$ & $\begin{array}{l}\text { v-e-r-at } \\
\text { DUR-go-DUR-INF } \\
\text { 'to travel' } \\
\text { azh-at }\end{array}$ \\
\hline
\end{tabular}

The circumfix v(i)-X-(e)r is used around verb stems to add a notion of duration to the action, while e(s)-X-(s)a negates the meaning of the verb: 


$$
\begin{array}{lll}
\text { gift-INF } & \rightarrow \quad(\mathrm{xx}) \quad \begin{array}{l}
\text { es-azh-a-lat } \\
\text { 'to gift' } \\
\end{array} \\
& \begin{array}{l}
\text { NEG-gift-NEG-INF } \\
\text { 'to take back' }
\end{array}
\end{array}
$$

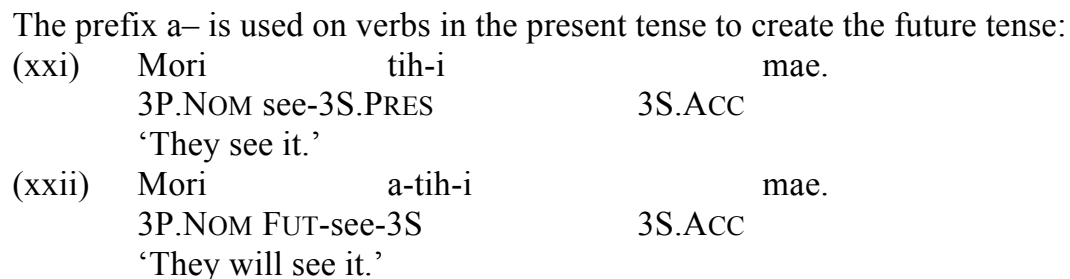

The suffix $-(a) k$ works as an agentive nominalizer to turn verb stems into nouns (realized $-a k$ if the stem ends in a consonant, and $-k$ if the stem ends in a vowel). For example, dothra'to ride' becomes dothrak 'rider' and laj- 'to fight' becomes lajak 'warrior'. Similarly, the suffix - asar adds the notion of large group to a singular noun: fonak 'hunter' becomes fonakasar 'hunting party', and verak 'traveler' becomes verakasar 'caravan'.

As we can see, Dothraki uses discontinuous affixes, and is also prefixing and suffixing, which makes it consistent with Universal \#26.

28. If both the derivation and inflection follow the root, or they both precede the root, the derivation is always between the root and the inflection.

In Dothraki, Greenberg's (1963) Universals \#28 is confirmed. Derivation and inflection always follow the root, and the derivation is always between the root and the inflection:

$\begin{array}{cl}\text { (xxiii) } \quad \begin{array}{l}\text { laj-at } \\ \text { fight-INF } \\ \text { 'to fight' }\end{array} \\ \text { (xxiv) laj-ak } \quad \begin{array}{l}\text { fight-AGENNOMIN } \\ \text { 'warrior' }\end{array} \\ \text { (xxv) laj-ak-i } \\ \\ & \begin{array}{l}\text { fight- AGENNOMIN-P } \\ \text { 'warriors' }\end{array}\end{array}$

We can see in (xxxviii) that the derivational affix $-a k$ - is located between the root and the plural inflection $-i$. Therefore, Dothraki is consistent with Universal \#28.

29. If a language has inflection, it always has derivation.

In Dothraki, Greenberg's (1963) Universals \#29 is confirmed. We saw in Universal \#28 that Dothraki has inflection and derivation.

30. If the verb has categories of person-number or if it has categories of gender, it always has tense-mode categories.

In Dothraki, Greenberg's (1963) Universals \#30 is confirmed. Dothraki has categories for person-number as well as tense-mode. The full conjugation of a verb, for example dothralat 'to ride', demonstrates this fact:

Infinitive:

dothra-lat: to ride.INF 


\begin{tabular}{|c|c|c|}
\hline \multicolumn{3}{|l|}{ Indicative } \\
\hline$\overline{\text { Present }}$ & Past & Future \\
\hline dothra-k & dothra-Ø & a-dothra-k \\
\hline ride-1S.PRES & ride- $1 \mathrm{~S} . \mathrm{PST}$ & FUT.ride.1S \\
\hline dothra-e & dothra- $\varnothing$ & a-dothra-e \\
\hline ride-2S.PRES & ride-2S.PST & FuT.ride. $2 \mathrm{~S}$ \\
\hline dothra-e & dothra- $\varnothing$ & a-dothra-e \\
\hline ride-3S.PRES & ride-3S.PST & FuT.ride.3S \\
\hline dothra-ki & dothra-sh & a-dothra-ki \\
\hline ride-1P.PRES & ride-1P.PST & FUT.ride.1P \\
\hline dothra-e & dothra-sh & a-dothra-e \\
\hline ride-2P.PRES & ride.2P.PST & FUT.ride.2P \\
\hline dothra-e & dothra-sh & a-dothra-e \\
\hline ride-3P.PRES & ride.3P.PsT & FUT.ride.3P \\
\hline Imperative & & \\
\hline dothra-Ø & & \\
\hline ride-PRES.IMP.FORM & & \\
\hline dothra-s & & \\
\hline ride-PRES.IMP.INFORM & & \\
\hline
\end{tabular}

We can see a distinction in person (first person singular dothrak vs. second person singular dothrae) and number (first person singular dothrak vs. first person plural dothraki) in the indicative, as well as a distinction in tense (present 1S dothrak vs. past 1S dothra vs. future 1S adothrak) and mode (present indicative 2S dothrae vs. present imperative 2S dothra/dothras). Therefore, Dothraki is consistent with Universal \#30.

35. There is no language in which the plural does not have some nonzero allomorphs, whereas there are languages in which the singular is expressed only by zero. The dual and the trial are almost never expressed only by zero.

In Dothraki, Greenberg's (1963) Universals \#35 is confirmed. In Dothraki, the singular is expressed by zero in the nominative, and the plural has only nonzero allomorphs.

$\begin{array}{lll}\text { (xxvi) } & \begin{array}{l}\text { Rizh- } \varnothing \\ \text { Son-S.Nom } \\ \text { 'The son rides.' }\end{array} & \text { dothra-e. } \\ \text { (xxvii) } & \begin{array}{l}\text { Rizh-i } \\ \text { Son-P.Nom } \\ \text { 'The sons ride.' }\end{array} & \begin{array}{l}\text { dothra-e. } \\ \text { ride-3P }\end{array}\end{array}$

We can see that the singular nominate marker is null, whereas all plural case markers such as the plural nominative in $(\mathrm{lx})$ are nonzero. Therefore, Dothraki is consistent with Universal \#35.

40. When the adjective follows the noun, the adjective expresses all the inflectional categories of the noun. In such cases the noun may lack overt expression of one or all of these categories.

In Dothraki, Greenberg's (1963) Universals \#40 is confirmed. Adjectives agree in number and case with the noun they modify. Even though inanimate nouns do not decline between singular and plural, if an adjective is modifying the noun, it will still agree with it:

(xxviii) Rakh-Ø

Boy-ANIM.S.NOM
haj-Ø

strong-S.NOM 


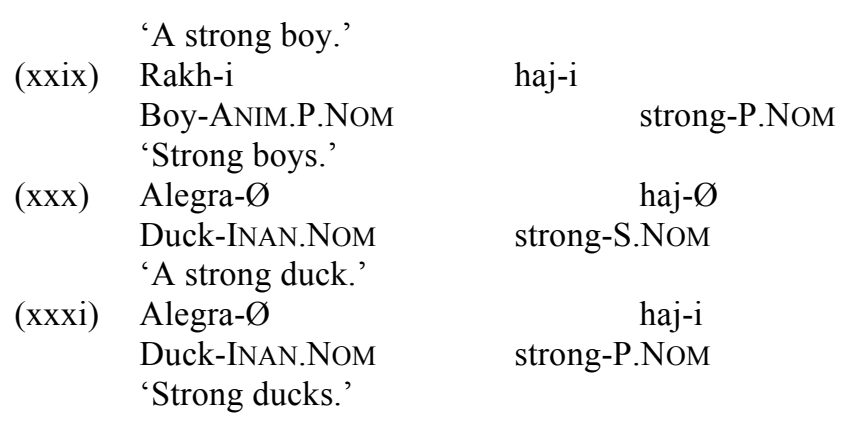

We can see in (1) and (li) that the animate noun rakh 'boy' declines for number, and the adjective agrees with it. On the other hand, the noun alegra 'duck' in (lii) and (liii) is inanimate. Therefore, it does not decline for number, but the adjective still needs to agree in number when the sentence is referring to multiple ducks.

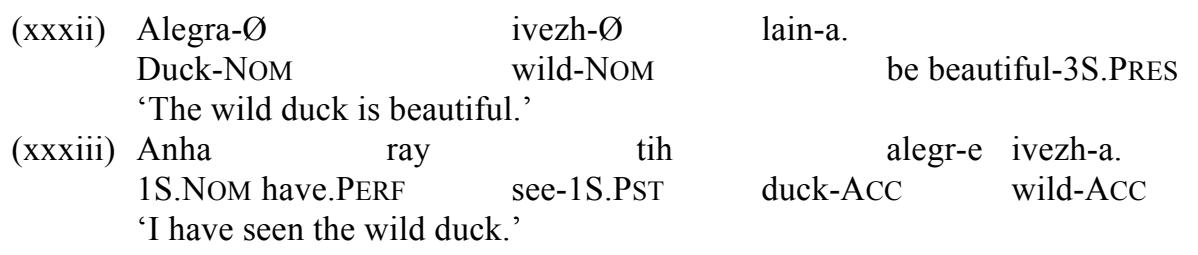

We can see that the adjective ivezh 'wild' agrees with the case of the noun alegra 'duck', either the nominative in (liv) or the accusative in (lv).

Based on this data, we can see that adjectives always follow nouns and must express all inflectional categories of the noun. Therefore, Dothraki is consistent with Universal \#40.

42. All languages have pronominal categories involving at least three persons and two numbers.

In Dothraki, Greenberg's (1963) Universals \#42 is confirmed. We have seen examples of three persons (1, 2 and 3 ) and two numbers ( $\mathrm{S}$ and $\mathrm{P})$, which the sentences below exemplify:

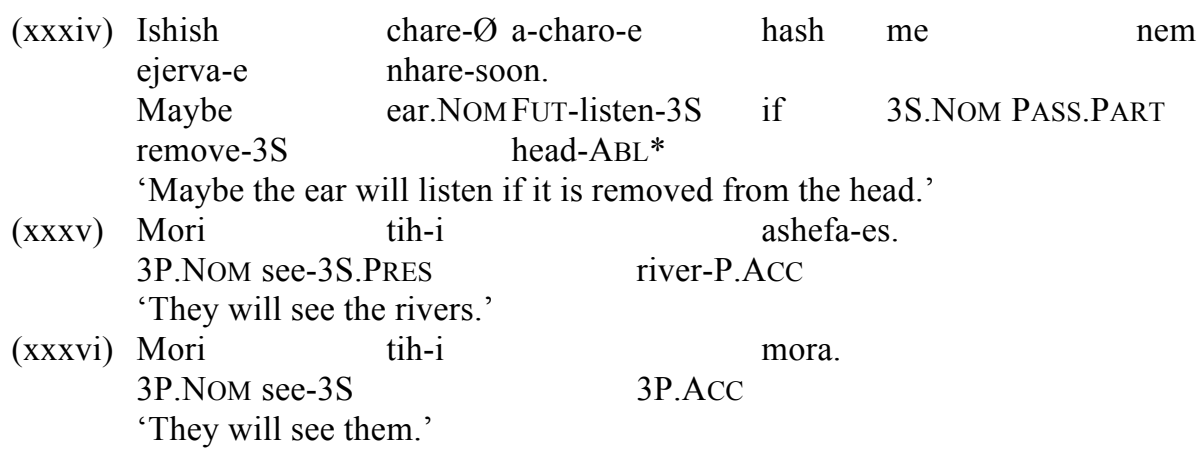

The existence of three persons and two numbers in Dothraki can be evidenced in (lviii) above for example. Indeed, chare 'ear' and $m e$ 'it' are coindexed, indicating the existence of a third person singular. In (lix) and (lx), ashefaes 'rivers' and mora 'they' indicate the existence of a third person plural. Therefore, Dothraki is consistent with Universal \#42.

\section{CONCLUSION}


Based on the survey established in part 2, and the data analyzed in part 3, we can assert that Dothraki functions very much like a natural language, and follows Greenberg's (1963) universals rigorously. All 15 universals that are relevant in Dothraki are confirmed in the language, exceeding Peterson's expectations. Dothraki is therefore typologically tractable, and could be studied further. For example, the language uses word order, case and agreement to identify its constituents, a process that might appear redundant or unnecessary. However, agreement (especially plurality) seems to be looser than the other two categories, and deserves more analysis. Similarly, the notion of animacy appears to have multiple facets that have not been studied in this paper, encouraging further research. 


\section{WORKS Cited}

Greenberg, Joseph H. 1963. Universals of Human Language, 73-113. Cambridge, Mass: MIT Press.

Dothraki.com. 2011.<http://www.dothraki.com>

Dothraki response to a call for science in a created language. 2010.

$<$ http://blogs.scientificamerican.com/guest-blog/2010/06/03/the-dothraki-response-to-a-call-forscience-in-a-created-language $>$

DothraWiki. 2013. <http://wiki.dothraki.org/Main_Page>

Official HBO Press Release. 2000. <http://dothraki.conlang.org/official-hbo-press-release>

Unofficial Dothraki Dictionary. 2011. <http://www.dothraki.org>

"Dothraki Language". Wikipedia. 2001. <http://en.wikipedia.org/wiki/Dothraki> 


\section{APPENDIX \\ Applicability of Greenberg's Linguistic Universals \\ Universals Irrelevant in Dothraki}

\section{Languages with dominant VSO order are always prepositional.}

4. With overwhelmingly greater than chance frequency, languages with normal SOV order are postpositional.

5. If a language has dominant SOV order and the genitive follows the governing noun, then the adjective likewise follows the noun.

6. All languages with dominant VSO order have SVO as an alternative or as the only alternative basic order.

7. If in a language with dominant SOV order there is no alternative basic order, or only OSV as the alternative, then all adverbial modifiers of the verb likewise precede the verb.

In Dothraki, Greenberg's (1963) Universals \#3-7 are irrelevant since we established in Universal \#1 that word order in Dothraki is SVO.

8. When a yes-no question is differentiated from the corresponding assertion by an intonational pattern, the distinctive intonational features of each of these patterns are reckoned from the end of the sentence rather than from the beginning.

In Dothraki, Greenberg's (1963) Universals \#8 is irrelevant. Basic questions start with a question word, for example the interrogative particle hash or the interrogative pronoun fin. Questions then follow the normal SVO word order, and no intonation is used to mark yes-no questions.

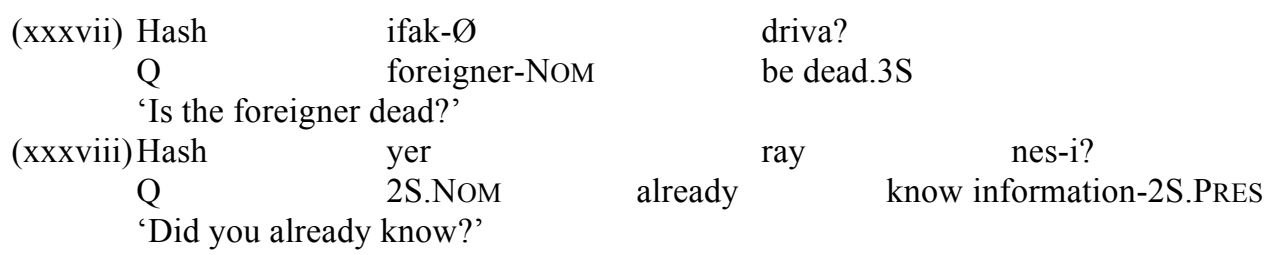

Therefore, Universal \#8 does not apply to Dothraki since intonation plays no part in question formation.

10. Question particles or affixes, when specified in position by reference to a particular word in the sentence, almost always follow that word. Such particles do not occur in languages with dominant order VSO.

In Dothraki, Greenberg's (1963) Universals \#10 is irrelevant. As we have seen in Universal \#8, question particles are sentence-initial and therefore are not specified in position by reference to a particular word in the sentence. 
11. Inversion of statement order so that verb precedes subject occurs only in languages where the question word or phrase is normally initial. This same inversion occurs in yes-no questions only if it also occurs in interrogative word questions.

In Dothraki, Greenberg's (1963) Universal \#11 is irrelevant. Even though question words are initial, as seen in (vii) below, there is no inversion of the word order in interrogative sentences compared to demonstrative ones (viii).

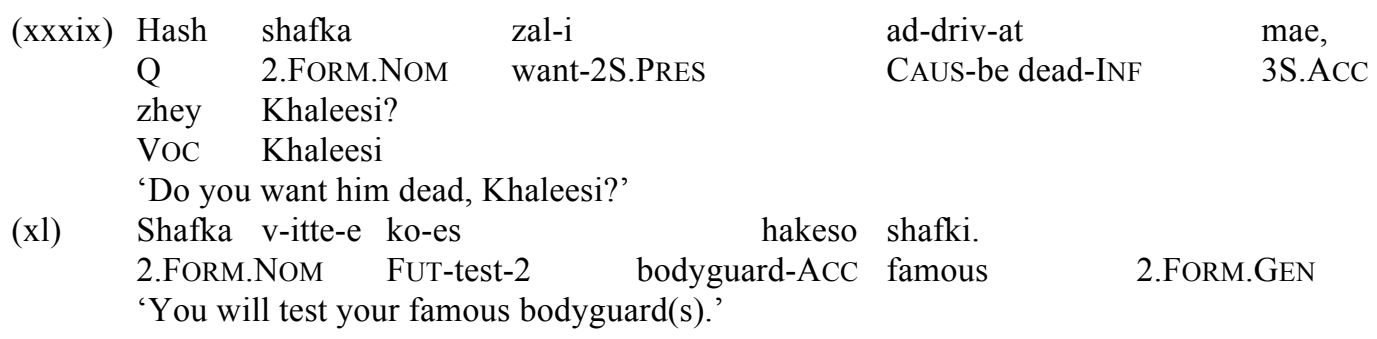

Dothraki remains SVO in affirmative and interrogative sentences alike. Therefore, Universal \#11 does not apply to Dothraki.

12. If a language has dominant order VSO in declarative sentences, it always puts interrogative words or phrases first in interrogative word questions; if it has dominant order SOV in declarative sentences, there is never such an invariant rule.

In Dothraki, Greenberg's (1963) Universals \#12 is irrelevant. Indeed, we saw in Universal \#1 that the word order in Dothraki is SVO.

13. If the nominal object always precedes the verb, then verb forms subordinate to the main verb also precede it.

In Dothraki, Greenberg's (1963) Universal \#13 is irrelevant since nominal objects do not precede the verb. Incidentally, subordinate verb forms do precede the verb.

$\begin{array}{llrrr}\text { (xli) } \begin{array}{l}\text { Anha jif } \\ \text { 1S.Nom should }\end{array} & \begin{array}{l}\text { ad-driv-ak } \\ \text { 'I should kill the man.' }\end{array} & \text { mahrazh-es. } \\ \text { (xlii) } \begin{array}{l}\text { Anha dead-1S.PRES } \\ \text { 1S.Nom can laz } \\ \text { 'I can kill the man.' }\end{array} & \text { ad-driv-ak } & & \text { mahrazh-es. } \\ & & & \end{array}$

We can see that in both sentences, the nominal object mahrazhes 'man' follows the verb addrivak 'kill'. Therefore, Universal \#13 does not apply to Dothraki. However, we can notice that subordinate verb forms, such as the auxiliaries jif 'should' and laz 'can', do precede the verb.

16. In languages with dominant order VSO, an inflected auxiliary always precedes the main verb. In languages with dominant order SOV, an inflected auxiliary always follows the main verb.

17. With overwhelmingly more than chance frequency, languages with dominant order VSO have the adjective after the noun. 
In Dothraki, Greenberg's (1963) Universals \#16 and 17 are irrelevant. We saw in Universal \#1 that Dothraki is SVO.

18. When the descriptive adjective precedes the noun, the demonstrative and the numeral, with overwhelmingly more than chance frequency, do likewise.

In Dothraki, Greenberg's (1963) Universals \#18 is irrelevant. The following sentences demonstrate the position of adjectives in Dothraki:

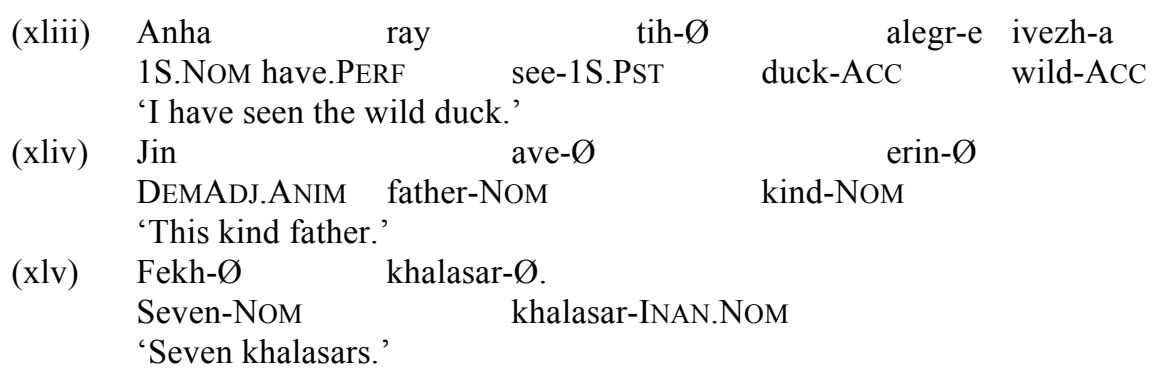

Sentences (xvi) and (xvii) show that demonstrative and numeral adjective precede the noun they modify (jin ave lit. 'this father' and fekh khalasar lit. 'seven khalasar). Despite this fact, we can see in (xvi) and (xvii) that descriptive adjectives follow the noun they modify (alegre ivezha lit. 'duck wild' and ave erin lit. 'father kind'). Therefore, Universal \#18 does not apply to Dothraki.

19. When the general rule is that the descriptive adjective follows, there may be a minority of adjectives which usually precede, but when the general rule is that descriptive adjectives precede, there are no exceptions.

In Dothraki, Greenberg's (1963) Universals \#19 is not really addressed. We saw in sentences (xvi) and (xvii) above that descriptive adjectives follow the noun they modify. However, there is no minority of adjectives that precede the noun. Therefore, Universal \#19 does not really address Dothraki.

21. If some or all adverbs follow the adjective they modify, then the language is one in which the qualifying adjective follows the noun and the verb precedes its nominal object as the dominant order.

In Dothraki, Greenberg's (1963) Universals \#21 is irrelevant. Adverbs always precede the adjective they modify:

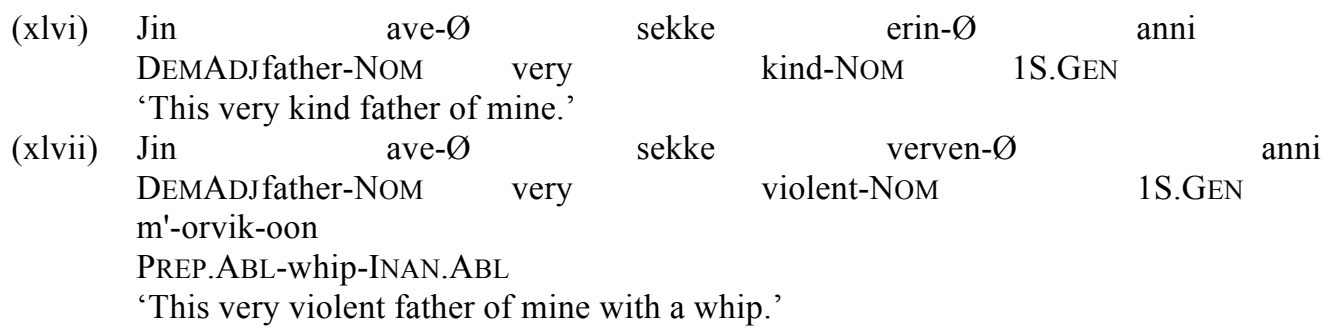

We can see that the adverb sekke 'very' precedes the adjective it modifies, either erin 'kind' in (xix) or verven 'violent' in (xx). Therefore, Universal \#21 does not apply to Dothraki. 
24. If the relative expression precedes the noun either as the only construction or as an alternate construction, either the language is postpositional, or the adjective precedes the noun, or both.

In Dothraki, Greenberg's (1963) Universals \#24 is irrelevant. Relative clauses always follow the noun they qualify:

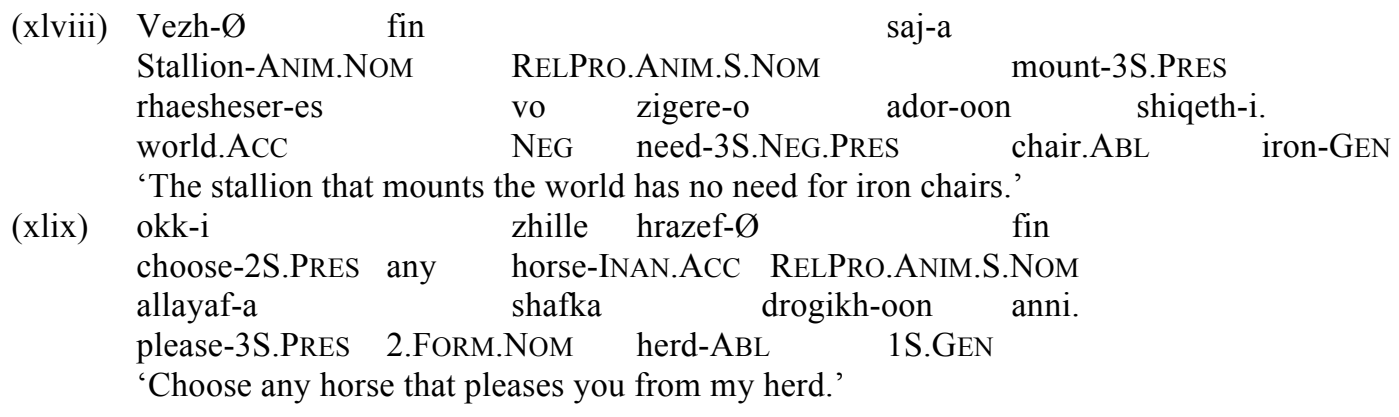

We can see that the relative clauses introduced by the relative pronoun fin 'that/who' always follow the noun they qualify. Therefore, Universal \#24 does not apply to Dothraki.

27. If a language is exclusively suffixing, it is postpositional; if it is exclusively prefixing, it is prepositional.

In Dothraki, Greenberg's (1963) Universals \#27 is irrelevant. We established in Universal \#26 that Dothraki is both prefixing and suffixing.

31. If either the subject or object noun agrees with the verb in gender, then the adjective always agrees with the noun in gender. Dothraki:

In Dothraki, Greenberg's (1963) Universals \#31 is irrelevant. There is no gender in

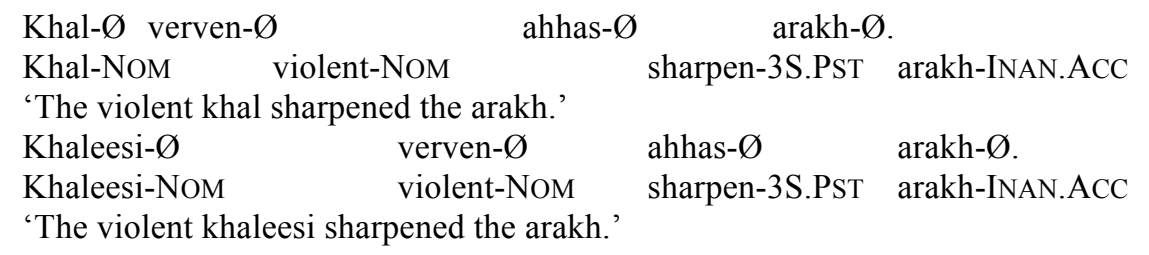

There is no trace of gender differences between these two otherwise identical sentences. Adjectives do not agree in gender with the noun they modify, and nouns are not inflected for gender. Additionally, the absence of definite and indefinite articles in Dothraki prevents their use as gender indicators.

32. Whenever the verb agrees with a nominal subject or nominal object in gender, it also agrees in number.

In Dothraki, Greenberg's (1963) Universals \#32 is irrelevant. We saw in Universal \# 31 that there is no gender in Dothraki.

33. When number agreement between the noun and verb is suspended and the rule is based on order, the case is always one in which the verb precedes and the verb is in the singular. 
In Dothraki, Greenberg's (1963) Universals \#33 is irrelevant. Nominal subjects always precede the verb and agree with it in person and number. Objectival nouns, which come after the verb, never agree with it:

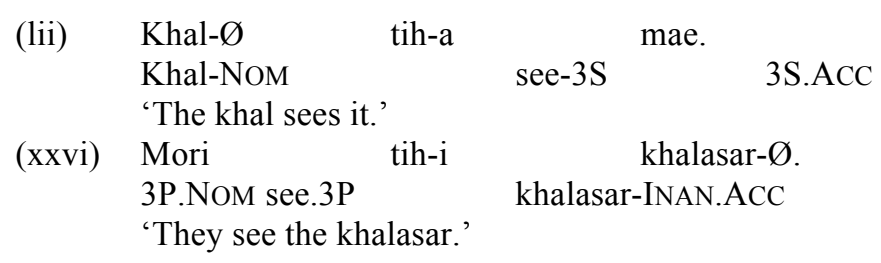

We can see that the nominal subject khal in (xli) precedes the verb tiha 'to see', which agrees with it in person and number. On the other hand, nouns placed after the verb are never the subject, and thus do not agree with it. Therefore, Universal \#33 does not apply to Dothraki.

34. No language has a trial number unless it has a dual. No language has a dual unless it has a plural.

In Dothraki, Greenberg's (1963) Universals \#34 is irrelevant. Dothraki only has singular and plural numbers.

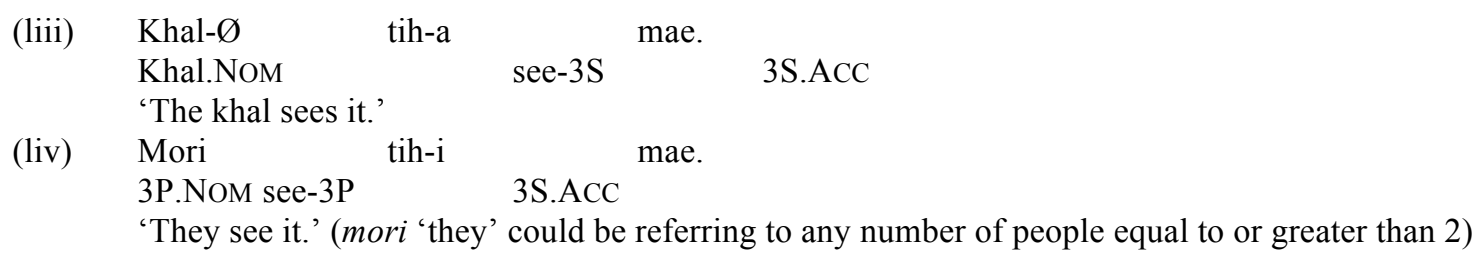

There is no evidence of a dual or trial number in Dothraki. Therefore, Universal \#34 does not apply to the language.

36. If a language has the category of gender, it always has the category of number.

In Dothraki, Greenberg's (1963) Universals \#36 is irrelevant. We established in Universal \#30 that Dothraki has number, but in Universal \# 31, we saw that it does not have gender. Therefore, Universal \#36 does not apply to Dothraki.

37. A language never has more gender categories in nonsingular numbers than in the singular.

In Dothraki, Greenberg's (1963) Universals \#37 is irrelevant. We saw in Universal \# 31 that there is no gender in Dothraki.

38. Where there is a case system, the only case which ever has only zero allomorphs is the one which includes among its meanings that of the subject of the intransitive verb.

In Dothraki, Greenberg's (1963) Universals \#38 is impossible to test. Peterson has not indicated that there are allomorphs in Dothraki. Therefore, Universal \#38 cannot be tested.

39. Where morphemes of both number and case are present and both follow or both precede the noun base, the expression of number almost always comes between the noun base and the expression of case. 
In Dothraki, Greenberg's (1963) Universals \#39 is irrelevant. Different case markers are used based on number:

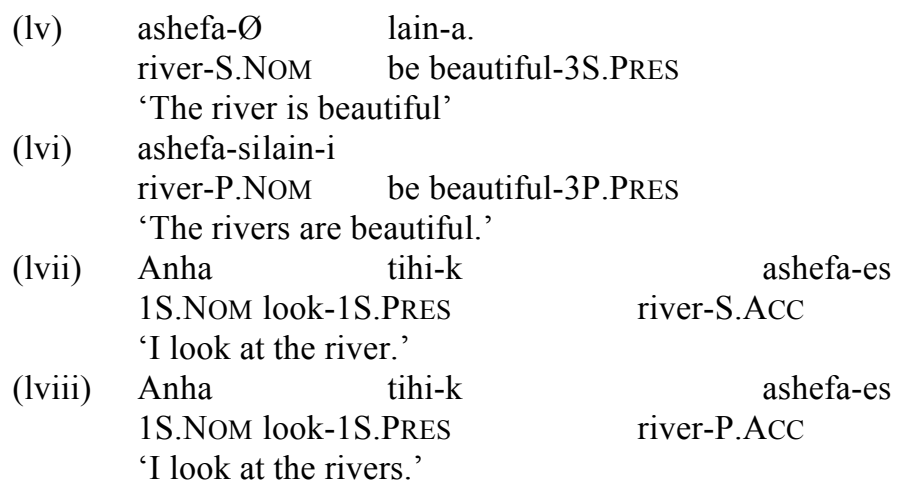

We can see that case and number markers in Dothraki are fused. For example, the marker $-s i$ in (xlvii) is both a nominative marker and a plural marker. Therefore, Universal \#39 does not apply to Dothraki.

41. If in a language the verb follows both the nominal subject and nominal object as the dominant order, the language almost always has a case system.

In Dothraki, Greenberg's (1963) Universals \#41 is irrelevant. Even though verbs follow nominal subjects, they precede nominal objects:

\begin{tabular}{|c|c|c|}
\hline (lix) & Khal- $\varnothing \quad$ ahhas- $\varnothing$ & arakh- $\varnothing$. \\
\hline & $\begin{array}{l}\text { Shal.NOM } \\
\text { 'The khal sharpened the arakh.' }\end{array}$ & \\
\hline & Anha ray & ivezh-a. \\
\hline & $\begin{array}{l}\text { 1S.NOM have.PERF see-1S.PST } \\
\text { 'I have seen the wild duck.' }\end{array}$ & duck-ACC \\
\hline
\end{tabular}

We can see that the verb always follows the nominal subjects such as khal and anha 'I', but it precedes nominal objects such as arakh and alagre 'duck'. Therefore, Universal \#41 does not apply to Dothraki.

43. If a language has gender categories in the noun, it has gender categories in the pronoun.

44. If a language has gender distinctions in the first person, it always has gender distinctions in the second or third person, or in both.

45. If there are any gender distinctions in the plural of the pronoun, there are some gender distinctions in the singular also.

In Dothraki, Greenberg's (1963) Universals \#43-45 are irrelevant. We saw in Universal \# 31 that there is no gender in Dothraki. 